\title{
Measurement of zinc flux through plasma in normal and endotoxin-stressed pigs and the effects of $\mathrm{Zn}$ supplementation during stress
}

\author{
BY J. K. CHESTERS AND MARIE WILL \\ Rowett Research Institute, Bucksburn, Aberdeen AB2 9SB
}

(Received 30. June 1980 - Accepted 24 February 1981)

1. The rates of transport of zinc through plasma have been investigated in normal and endotoxin-stressed pigs.

2. ${ }^{\circ} \mathrm{Zn}$ added to porcine plasma in vitro rapidly equilibrated with the $\mathrm{Zn}$ originally present.

3. ${ }^{\circ} \mathrm{Zn}$ bound to albumin and injected intravascularly into pigs rapidly equilibrated with two kinetically distinguishable pools. The first of these pools was mainly associated with the plasma but was significantly larger than the plasma volume and substantially so in $\mathrm{Zn}$-deficient pigs. The second pool appeared to represent a summation of the rapidly-exchangeable $\mathrm{Zn}$ within the extravascular tissues.

4. In non-stressed animals, the flux of $\mathrm{Zn}$ from the plasma of $\mathrm{Zn}$-deficient pigs was only half that in Zn-supplemented animals.

5. Administration of endotoxin reduced the plasma $\mathrm{Zn}$ concentration of $\mathrm{Zn}$-supplemented pigs but not of $\mathrm{Zn}$-deficient animals. The fract ional turnover rates of $\mathrm{Zn}$ were not altered in either of the two pools following endotoxin.

6. At $10 \mathrm{~h}$ after giving endo:oxin neither the $\mathrm{Zn}$ content of the two pools nor the flux of $\mathrm{Zn}$ through them differed significantly between $\mathrm{Zn}$-deficient and control pigs.

7. Intravascular infusion of $\mathrm{Zn}$ at a rate which essentially prevented the usual depression in plasma $\mathrm{Zn}$ concentration following endotoxin failed to alleviate the effects of endotoxin on $\mathrm{Zn}$-supplemented pigs.

8. The reduction in plasma $\mathbf{Z n}$ concentration following endotoxin stress appears to be a normal physiological response which is not indicative of an increased metabolic requirement for $\mathrm{Zn}$.

Stresses such as acute infection, post-operative shock and pregnancy have been shown to reduce plasma zinc concerttration in man (Vikbladh, 1951; Pekarek et al. 1970; Hambidge \& Droegemueller, 1974; $\mathrm{H}$ allbook \& Hedelin, 1977). In most cases investigated there was also a parallel reduction in plasma iron concentration and often a delayed increase in copper in caeruloplasmin in blood. Similar effects of stress have been reported in a range of animal species (Pekarek \& Beisel. 1969; Corrigall et al. 1976; Whitenack et al. 1978).

The reduction in plasma concentration of Fe following stress has been postulated to have a protective function by limiting the availability of $\mathrm{Fe}$ to bacteria and hence reducing the risk of septicaemia (Buller et al. 1978; Weinberg, 1978). A similar proposal has been made with regard to the effect of stress on plasma $\mathrm{Zn}$ concentration (Weinberg, 1974). However, the reduction in $\mathrm{Zn}$ concentration following stress is frequently comparable in magnitude to that caused by dietary deficiency of $\mathrm{Zn}$. This has led to an alternative suggestion that stressed animals may have; an increased metabolic requirement for $\mathrm{Zn}$ and to at least one clinical trial of $\mathrm{Zn}$ supplementation to test this idea (Kumar, 1976; Hallbook \& Hedelin, 1978).

All previous reports have dealt only with the change in the concentration of $\mathrm{Zn}$ in plasma whereas the physiologically important factor is probably the flux of $\mathrm{Zn}$ (quantity of $\mathrm{Zn}$ passing through plasma in unit time) which is not necessarily directly related to $\mathrm{Zn}$ concentration. The presen: paper concerns investigations of the flux of $\mathrm{Zn}$ in normal and stressed pigs and in pigs vith clinical symptoms of $\mathrm{Zn}$ deficiency induced by inadequate dietary $\mathrm{Zn}$ intake. Also reported are the effects of intravenous supplementation of stressed pigs with sufficient $\mathrm{Zn}$ to prevent the usual fall in plasma $\mathrm{Zn}$ concentration. 


\section{EXPERIMENTAL}

\section{Animals and diets}

Large white $\times$ Landrace gilts weighing $25-35 \mathrm{~kg}$ were fitted with bilateral catheters into the abdominal aorta via the saphenous arteries by the method of Scott \& McIntosh (1975). One catheter, which was used for the infusion or injection of substances was $75 \mathrm{~mm}$ shorter than and thus terminated down-stream of the other which was used for obtaining blood samples.

After catheterization the pigs were given diets containing ground maize $(750 \mathrm{~g} / \mathrm{kg})$, soya bean meal $(200 \mathrm{~g} / \mathrm{kg})$ and vitamin and mineral supplements. The vitamin supplement (M952, Isaac Spencer, Aberdeen) provided (mg/ $\mathrm{kg}$ diet) retinol $1 \cdot 2$, cholecalciferol 0.02 , riboflavin 2, vitamin $\mathrm{E} 2$, vitamin $\mathrm{K}$ 1, pantothenic acid 5, nicotinic acid 10, cyanocobalamin 0.006 and the mineral supplement supplied $(\mathrm{g} / \mathrm{kg}$ diet $)$ sodium chloride 5 , calcium carbonate $20, \mathrm{CaHPO}_{4} \cdot 2 \mathrm{H}_{2} \mathrm{O} 20$ plus essential trace elements. The latter provided the following supplementary concentrations in the final diets $(\mathrm{mg} / \mathrm{kg})$ : copper 20 , manganese 70 , iron 70 , cobalt 1 and iodine 1 . In addition $\mathrm{Zn}$ was added to the control diet as $\mathrm{ZnSO}_{4} \cdot 7 \mathrm{H}_{2} \mathrm{O}$ to give an additional $\mathrm{Zn}$ concentration of $100 \mathrm{mg} / \mathrm{kg}$. The unsupplemented, $\mathrm{Zn}$-deficient diet contained $23-25 \mathrm{mg} \mathrm{Zn} / \mathrm{kg}$ with a value of approximately 40 for the molar ratio phytate: $\mathrm{Zn}$. Weighed quantities of diet were mixed with half their weight of water and offered to the pigs individually in daily amounts in excess of appetite. The weight of diet consumed was recorded daily.

The $\mathrm{Zn}$ metabolism of the pigs was investigated when they reached a weight of $42-45 \mathrm{~kg}$ by which time the pigs given the unsupplemented diets were $\mathrm{Zn}$-deficient as assessed by a reduction in growth rate and food intake, low plasma $\mathrm{Zn}$ concentration and clinical signs of parakeratosis. Samples of blood taken from the indwelling catheters were prevented from clotting by addition of sodium heparin (final concentration $100 \mathrm{I} . \mathrm{U} . / \mathrm{ml}$ ) or by addition of sodium fluoride (final concentration $0.24 \mathrm{M}$ ) when the distribution of $\mathrm{Zn}$ within the plasma was being investigated. For experiments in which the urinary outputs of nitrogen, $\mathrm{Zn}$ and ${ }^{65} \mathrm{Zn}$ were measured, the pigs were fitted with Silicath bladder catheters (Travenol Laboratories, Thetford, Norfolk) and urine was collected into $2 \mathrm{M}$-sulphuric acid to prevent loss of $\mathrm{N}$ and bacterial growth.

\section{Separation of $\mathrm{Zn}$-albumin from plasma}

${ }^{65} \mathrm{Zn}$ was added to fluoride-treated plasma and after a $5 \mathrm{~h}$ equilibration period at room temperature, the samples were chromatographed on Sephadex G-100 and the fractions analysed as described by Chesters \& Will (1981).

Polyethylene glycol precipitation was investigated as an alternative method for the separation of $\mathrm{Zn}$-albumin from porcine plasma (Giroux, 1975). A mixture containing $40 \mathrm{~mm}$-phosphate buffer, $\mathrm{pH} 7.4(2.5 \mathrm{ml}), 0.15 \mathrm{M}-\mathrm{NaCl}(2.0 \mathrm{ml})$ and $3.0 \mathrm{ml}$ polyethylene glycol 6000 (500 g/1, Sigma Chemical Co., London) was cooled to $0^{\circ}$ and either fluoridetreated whole blood or plasma $(2.5 \mathrm{ml})$ was added. After mixing and being left at $0^{\circ}$ for $30 \mathrm{~min}$, the preparation was centrifuged at $1000 \mathrm{~g}$ for $15 \mathrm{~min}$ and the supernatant fraction was removed for investigation. In certain experiments the blood or plasma had been supplemented with ${ }^{125} \mathrm{I}$-labelled albumin and ${ }^{65} \mathrm{Zn}$ as for column chromatography before precipitation with polyethylene glycol. The distribution of both isotopes between soluble fraction and precipitate was then determined using a gamma counter (Gamma Guard 400; ICN-Tracerlab, Hersham, Surrey). In other instances, the soluble fraction was mixed with an equal volume of polyethylene glycol $(500 \mathrm{~g} / \mathrm{l})$ and after $40 \mathrm{~min}$ at $0^{\circ}$ the precipitated protein was recovered by centrifugation. This material, which contained all the proteinbound ${ }^{125} \mathrm{~T}$ in the original supernatant fraction, was dissolved in column buffer and chromatographed on Sephadex G-100 as previously described. 


\section{Determination of rates of disappearance of ${ }^{65} \mathrm{Zn}$ from plasma}

${ }^{65} \mathrm{Zn}(200 \mu \mathrm{Ci} ; 1.45 \mu \mathrm{Ci} / \mu \mathrm{g})$ and trace amounts of porcine albumin labelled with $4-5 \mu \mathrm{Ci}$ ${ }^{125}$ (Chesters \& Will, 1981) were added to $100 \mathrm{mg}$ purified albumin dissolved in $5 \mathrm{ml}$ pyrogen-free saline $(9 \mathrm{~g} \mathrm{NaCl} / \mathrm{l}$; Boots $\mathrm{Co}$. Ltd, Nottingham). The preparation was then injected into a pig weighing $42-45 \mathrm{~kg}$ via its distal arterial catheter using a Millex filter (Millipore (UK) Ltd, London) to ensure sterility of the solution. Samples of blood $(10 \mathrm{ml})$ were taken from the second, proximal catheter $2,3,4,6,9,12,15,20,30,45,60,90$ and $150 \mathrm{~min}$ after injection of the ${ }^{65} \mathrm{Zn} .{ }^{65} \mathrm{Zn}$ in the whole blood was measured in a large volume gamma counter (Nuclear Enterprises, Edinburgh) which was insensitive to the low-energy radiation from ${ }^{125}$. The samples were then centrifuged to obtain plasma. The radioactivity in the plasma from both ${ }^{65} \mathrm{Zn}$ and ${ }^{125}$ I was determined using a small volume, gamma scintillation counter (Gamma Guard 400, ICN-Tracerlab, Hersham, Surrey) and its total $\mathrm{Zn}$ content was measured by atomic absorption (Chesters \& Will, 1978). Small samples of the original blood were used for microhaematocrit determination to allow correction of whole blood radioactivity for the associated plasma activity.

Plasma volumes were calculated from the zero time intercept of a single exponential expression for the loss of ${ }^{125}$ I-labelled albumin from plasma derived from the values obtained 30-150 min after injection.

\section{Calculation of pool sizes, fractional turnover rates and $\mathrm{Zn}$ flux}

In the following discussion, fractional turnover rate and $\mathrm{Zn}$ flux both refer to the rate of loss of $\mathrm{Zn}$ from a pool. With the former, the rate of loss was measured in terms of the $\mathrm{Zn}$ content of the pool and was therefore expressed in pool changes per $\mathrm{h}$. For $\mathrm{Zn}$ flux, the loss was expressed in absolute units $(\mathrm{mg} / \mathrm{h})$. The two terms are therefore related by the following expression:

$$
\text { fractional turnover rate }=\frac{\mathrm{Zn} \text { flux }}{\mathrm{Zn} \text { content of pool }} .
$$

When the loss of ${ }^{65} \mathrm{Zn}$ from plasma was related to a single exponential decline, there was reasonable agreement with the values until $15 \mathrm{~min}$ after injection after which the experimental results departed significantly from the predicted values. Postulation of a second pool in relatively rapid equilibrium with the first accounted for better than $98 \%$ of the variance of the experimental values over the entire $90 \mathrm{~min}$ period and improved the fit of the theoretical curve to the experimental points even over the first $15 \mathrm{~min}$. The experimental results were therefore interpreted in terms of the two-pool model shown in Fig. 1, using the methods described by Shipley \& Clark (1972). The extent to which these methods accounted for the experimental values is illustrated in Fig. 2 which also illustrates the inadequacy of using a single exponential equation based on the values for the first $15 \mathrm{~min}$.

Analysis of the experimental results using the two pool model gave estimates of the fractional turnover rates of pools $a$ and $b$ and of their magnitude in terms of the equivalent volumes of plasma. The latter values were converted to quantities of $\mathrm{Zn}$ in equilibrium with the injected ${ }^{65} \mathrm{Zn}$ by assumning that one third of the total $\mathrm{Zn}$ in plasma was in equilibrium with ${ }^{65} \mathrm{Zn}$ at the moment of injection (see p. 127). The $\mathrm{Zn}$ content of each pool was therefore calculated by multiplying, its equivalent volume (1) by one third of the quantity of $\mathrm{Zn}$ in 11 of plasma. $\mathrm{Zn}$ flux was then calculated from the product of the $\mathrm{Zn}$ content of the pool and the corresponding fractional turnover rate. The differences between treatments and groups were analysed by split plot analysis of variance. 
$F_{\text {ba }}$

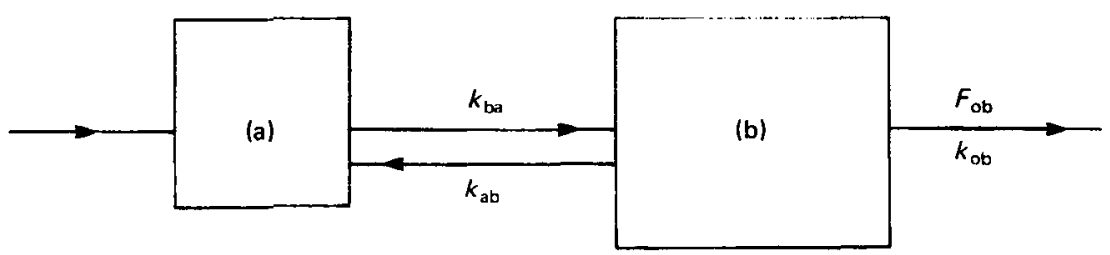

Fig. 1. Model of ${ }^{85} \mathrm{Zn}$ loss from the pool of $\mathrm{Zn}$ in equilibrium with plasma (pool a) and from the rapidly-exchanging $\mathrm{Zn}$ in tissues (pool b). Movement of ${ }^{65} \mathrm{Zn}$ was defined in terms of the fractional turnover rates $(k)$ of the pools and their volumes (equivalent 1 plasma).

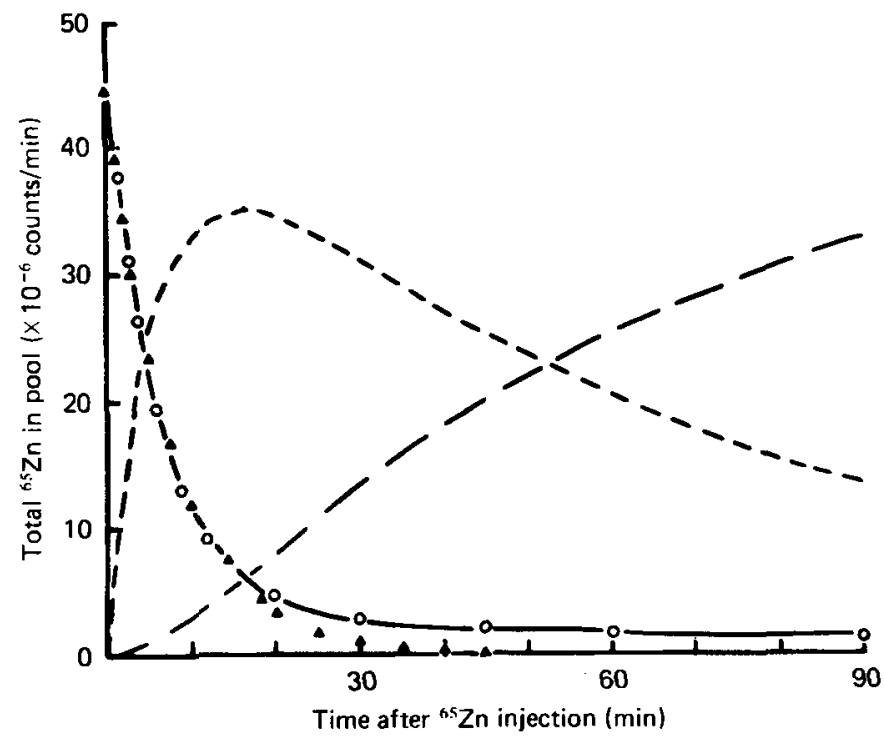

Fig. 2. Re-distribution of albumin-bound ${ }^{65} \mathrm{Zn}$ injected into the plasma of a non-stressed, $\mathrm{Zn}$-supplemented pig. (O), Experimental measurements of ${ }^{\circ 5} \mathrm{Zn}$ in pool a; (-) the fit of the double exponential equation to these points. (---), Calculated changes in ${ }^{65} \mathrm{Zn}$ content of pool $\mathbf{b} ;(--)$, the accumulated loss of ${ }^{63} \mathrm{Zn}$ to the less-rapidly-exchanging pools of the tissues based on the two pool model for ${ }^{85} \mathrm{Zn}$ loss. Also shown is the fit of values $(\Delta)$ calculated from a single-pool model based on the experimental results from the first $15 \mathrm{~min}$.

\section{Effect of endotoxin on Zn flux}

To investigate the effects of stress on $\mathrm{Zn}$ flux, pigs were injected with Escherichia coli endotoxin ( $200 \mu \mathrm{g} / \mathrm{kg}$ body-weight, serotype 055:B5; Difco Laboratories, West Molesey, Surrey) dissolved in pyrogen-free saline. Flux measurements were made $2 \mathrm{~h}$ and $10 \mathrm{~h}$ after endotoxin administration by the method described above except that on the second occasion five times the usual quantity of ${ }^{125}$ I-labelled albumin was used to produce a significant increase in ${ }^{125} \mathrm{I}$ above that remaining in plasma from the $2 \mathrm{~h}$ injection. The retention of ${ }^{65} \mathrm{Zn}$ in plasma $8 \mathrm{~h}$ after the first injection was not sufficient to cause problems of interpretation with the second injection (Fig. 2). 


\section{Effect of $\mathrm{Zn}$ infusion on the severity of the stress response}

To assess how the administration of $\mathrm{Zn}$ affects the response of pigs to endotoxin stress, identical doses of endotoxin $(200 \mu \mathrm{g} / \mathrm{kg}$ body-weight) were injected on two occasions 1 week apart. On both occasions the endotoxin was derived from Escherichia coli but to reduce problems caused by development of resistance after the first injection different serotypes (055:B5 and 026:B6; Difco Laboratories) were used for successive injections. For $24 \mathrm{~h}$ immediately following one of these challenges, the pigs were infused with $2 \mathrm{mg} \mathrm{Zn}$ as zinc sulphate dissolved in pyrogen-free saline $/ \mathrm{h}$ and administered at $18 \mathrm{ml} / \mathrm{h}$. On the other occasion the pigs were infused at the same rate with saline alone. Since Analar $\mathrm{ZnSO}_{4}$ was occasionally found to produce a febrile response the material used for infusion was first heated at $400^{\circ}$ for $24 \mathrm{~h}$ to destroy pyrogenic material.

The severity of the response of the pigs to endotoxin was assessed by measuring vaginal body temperature at $0.5 \mathrm{~h}$ intervals for the first $4 \mathrm{~h}$ and hourly thereafter. Blood samples were obtained hourly for $4 \mathrm{~h}$ and then every $2 \mathrm{~h}$. Food intake was recorded at the end of the $24 \mathrm{~h}$ and again $1 \mathrm{~d}$ later. Plasma obtained from the blood samples was used for the estimation of total $\mathrm{Zn}$ concentration by atomic absorption and for the determination of total bilirubin and aspartate aminotransferase (EC 2.6.1.1) activity by colorimetric methods (Sigma Kits No. 505 and 605; Sigma Chemical Co., London).

The results were assessed successively in four pigs. The order of administration of the two endotoxin serotypes and of the two types of infusion to the pigs was varied so that all possible sequences of administration were investigated. The effects of $\mathrm{Zn}$ infusion were then analysed for the group as a whole using within pig differences associated with $\mathrm{Zn}$ infusion to assess their significance.

\section{RESULTS}

Preliminary studies (Chesters \& Will, 1981) had suggested that albumin is quantitatively the most important $\mathrm{Zn}$-tinding protein in plasma of most species but that, in porcine plasma, $\mathrm{Zn}$ is also presint in similar amounts on $\alpha_{2}$-macroglobulin and on another component thought to te unique to porcine plasma. Some knowledge of the kinetic relationships of $\mathrm{Zn}$ bound to these components was necessary before flux measurements could be attempted.

When porcine plasma was chromatographed on Sephadex G-100 the distribution pattern of a tracer dose of ${ }^{85} \mathrm{Zn}$ added to the sample in vitro was identical to that of the intrinsic $\mathrm{Zn}$ of the plasma. Furthermore, the same was true even when the $\mathrm{Zn}$ concentration of the sample investigated was substantially reduced following administration of endotoxin or as a consequence of dietary deficiency. In all instances albumin-bound $\mathrm{Zn}$ accounted for approximately one third of the total $\mathrm{Zn}$ in the plasma.

For studies of the flux of $\mathrm{Zn}$, it was desirable, however, to be able to measure the instantaneous distribution of $\mathrm{Zn}$ and ${ }^{65} \mathrm{Zn}$ at the time the plasma was obtained whereas column chromatography allowed equilibration to occur for several hours before separation of the proteins was complete. Giroux (1975) and Burns \& Fell (1976) had reported that $\alpha_{2}$-macroglobulin and its associated $\mathrm{Zn}$ could be precipitated from human plasma by addition of polyethylene: glycol $(120 \mathrm{~g} / \mathrm{l})$. Investigation of porcine plasma showed that polyethylene glycol $(150 \mathrm{~g} / \mathrm{l})$ precipitated both $\alpha_{2}$-macroglobulin and all of the unknown $\mathrm{Zn}$-binding component while leaving most of the $\mathrm{Zn}$-albumin still soluble. Furthermore it proved possible to obtain the same separation of albumin free from other $\mathrm{Zn}$-binding proteins even when whole blood was used for the precipitation. However, when samples of blood taken from a pig $2.5 \mathrm{~min}$ after intra-arterial injection of ${ }^{65} \mathrm{Zn}$-albumin were immediately precipitated with polyethylene glycol, only one-third of the ${ }^{65} \mathrm{Zn}$ remained on albumin (Table 1). Furthermore even when the blood was mixed with ${ }^{65} \mathrm{Zn}$-albumin in vitro 
Table 1. Fractionation of ${ }^{65} \mathrm{Zn}$ in porcine blood by precipitation with polyethylene glycol

(The distributions of ${ }^{65} \mathrm{Zn}$ and ${ }^{125} \mathrm{I}$-labelled albumin between soluble and precipitated material were determined with samples of blood to which ${ }^{55} \mathrm{Zn}$ was added either in vitro or in vivo. In each instance the ${ }^{65} \mathrm{Zn}$ was bound to porcine albumin containing a trace amount of ${ }^{125}$ I-labelled albumin before being mixed with the blood)

\begin{tabular}{|c|c|c|c|c|}
\hline \multirow[b]{2}{*}{$\begin{array}{l}\text { Addition } \\
\text { of }{ }^{65} \mathrm{Zn}\end{array}$} & \multirow{2}{*}{$\begin{array}{l}\text { Delay between } \\
\text { addition of } \\
{ }^{65} \mathrm{Zn} \text { and } \\
\text { precipitation }\end{array}$} & \multicolumn{2}{|c|}{$\begin{array}{l}\text { Proportion of isotope } \\
\text { in soluble fraction }\end{array}$} & \multirow{2}{*}{$\begin{array}{l}\text { Proportion of }{ }^{65} \mathrm{Z} \\
\text { bound to albumin } \\
\text { in whole blood }\end{array}$} \\
\hline & & $\begin{array}{l}125 \text {-labelled } \\
\text { albumin }\end{array}$ & ${ }^{65} \mathrm{Zn}$ & \\
\hline In vivo & $2.5 \mathrm{~min}$ & 0.66 & 0.24 & 0.36 \\
\hline In vivo & $1.5 \mathrm{~h}$ & 0.62 & $0 \cdot 22$ & 0.36 \\
\hline In vitro & $0.5 \mathrm{~min}$ & 0.74 & $0 \cdot 18$ & $0 \cdot 24$ \\
\hline
\end{tabular}

and immediately precipitated with polyethylene glycol, still only approximately one-third of the ${ }^{65} \mathrm{Zn}$ remained bound to albumin, this being approximately the same proportion as that of the total $\mathrm{Zn}$ in plasma found on albumin. Equilibration of $\mathrm{Zn}$ between the various Zn-binding components of porcine plasma was either extremely rapid or continued to occur at $0^{\circ}$ even after precipitation of the bulk of the plasma proteins. In view of these findings it was decided that $\mathrm{Zn}$ flux through plasma would be measured by injecting ${ }^{65} \mathrm{Zn}$ bound to albumin and studying the loss of ${ }^{65} \mathrm{Zn}$ from total plasma rather than specifically from albumin.

The results from injection of ${ }^{65} \mathrm{Zn}$-albumin into normal, $\mathrm{Zn}$ deficient and endotoxin-stressed pigs are presented in Tables 2 and 3. Administration of endotoxin to normal pigs halved the concentration of $\mathrm{Zn}$ in plasma by $10 \mathrm{~h}$, a slight but significant reduction having occurred by $2 \mathrm{~h}$. However, the already low concentration of $\mathrm{Zn}$ in plasma of $\mathrm{Zn}$-deficient pigs was not altered by endotoxin.

In most groups pool a was significantly larger than the plasma volume indicating that ${ }^{65} \mathrm{Zn}$ was lost from plasma even before mixing was complete. Furthermore, pool a was proportionally much larger with respect to plasma volume in the $\mathrm{Zn}$-deficient pigs than in the $\mathrm{Zn}$-adequate animals. In both of these groups the size of pool a was markedly reduced $2 \mathrm{~h}$ after endotoxin, this reduction being such that pool a of the $\mathrm{Zn}$-adequate pigs was no longer significantly larger than their plasma volume. In both non-stressed pigs and in pigs $2 \mathrm{~h}$ after receiving endotoxin, the quantity of $\mathrm{Zn}$ in pool a was significantly less in the deficient than in the control pigs, the relatively large volume of pool a in the $\mathrm{Zn}$-deficient group not being sufficient to compensate for the low concentration of $\mathrm{Zn}$ in plasma. By $10 \mathrm{~h}$ after endotoxin, however, the $\mathrm{Zn}$ contents of pool $\mathrm{a}$ in normal and $\mathrm{Zn}$-deficient pigs did not differ significantly. Indeed at this time of maximum disturbance in the $\mathrm{Zn}$ metablolism of the $\mathrm{Zn}$-supplemented pigs, only the plasma $\mathrm{Zn}$ concentration and the volumes of pools a and $\mathrm{b}$ differed significantly with the dietary $\mathrm{Zn}$ intake of the two groups.

The volumes of pool $b$ were always significantly greater for each treatment in the $\mathrm{Zn}$-deficient than in the $\mathrm{Zn}$-supplemented groups but within groups the values $2 \mathrm{~h}$ after endotoxin tended to be lower than in non-stressed pigs or in those $10 \mathrm{~h}$ after endotoxin treatment. As would be expected the quantity of $\mathrm{Zn}$ in pool b was greater in the $\mathrm{Zn}$-supplemented than in $\mathrm{Zn}$-deficient pigs under all conditions. This difference was not however statistically significant $10 \mathrm{~h}$ after endotoxin.

Although differences in $\mathrm{Zn}$ nutrition influenced the volumes and $\mathrm{Zn}$ contents of pools $a$ and $b$ they had remarkably little effect upon their fractional turnover rates. In non-stressed pigs the fractional turnover rate of pool a was increased significantly by $\mathrm{Zn}$ deficiency but 
2In flux through plasma of stressed pigs

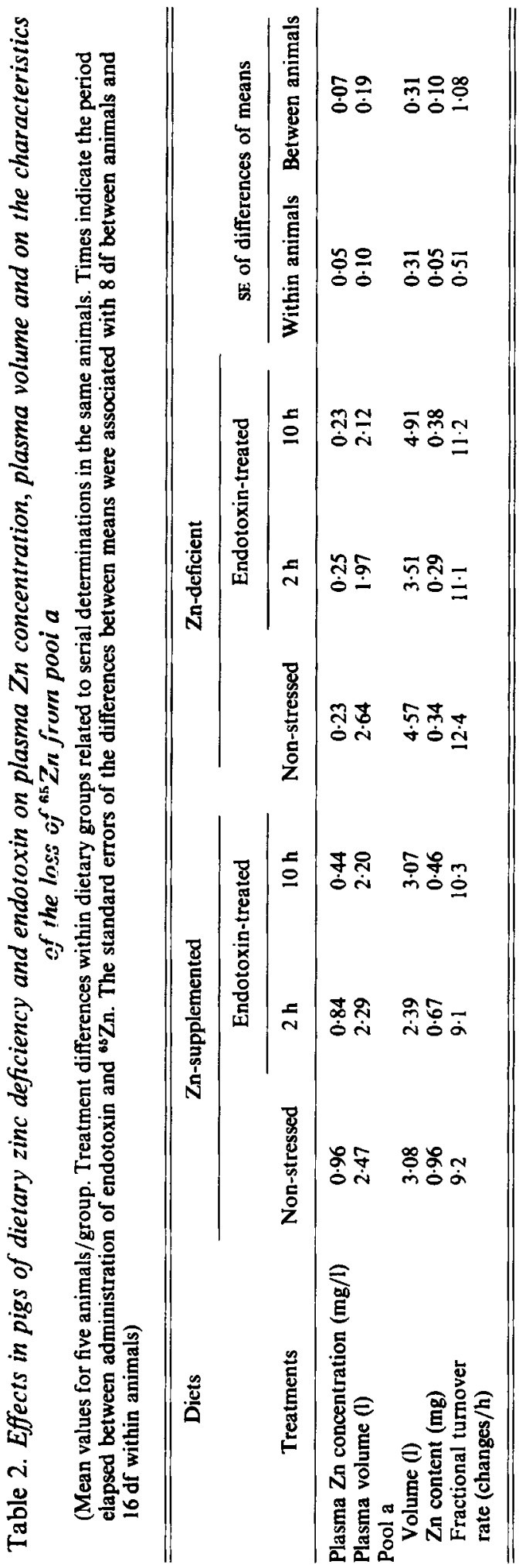


J. K. Chesters and M. Will

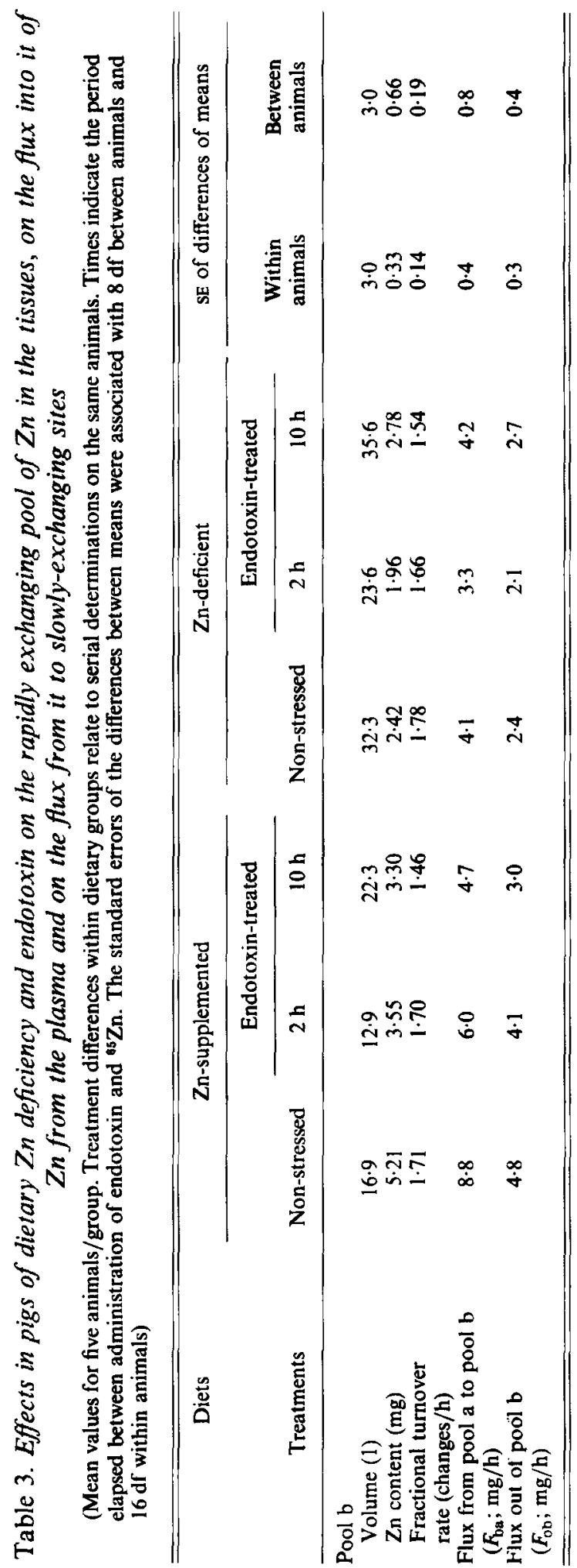


this was not sufficient to compensate for its reduction in $\mathrm{Zn}$ content. The fractional turnover rates of pool $b$ were not significantly altered by the $\mathrm{Zn}$ status of the pigs. As a consequence, the changes in $\mathrm{Zn}$ flux reflected mainly the differences in the amounts of $\mathrm{Zn}$ in the pools. Dietary $\mathrm{Zn}$ deficiency resulted in relatively low fluxes of $\mathrm{Zn}$ through plasma and out of the readily-exchangeable pool of the tissues. However, these fluxes were not significantly altered by endotoxin. In contrast, the much higher fluxes of $\mathrm{Zn}$ in normal pigs were reduced by endotoxin treatment and at the time of its maximum effect, they were not significantly different in animals which had been receiving diets deficient in or supplemented with $\mathrm{Zn}$.

The significance of the reduction in $\mathrm{Zn}$ flux after endotoxin administration was investigated by infusing stressed pigs with physiological saline or saline plus $\mathrm{Zn}$. The rate of $\mathrm{Zn}$ infusion chosen $(2 \mathrm{mg} / \mathrm{h})$ was based on the difference in the flux of $\mathrm{Zn}$ from pool $\mathrm{b}$ before stressing and $10 \mathrm{~h}$ after endotoxin. This proved marginally inadequate to prevent fully a reduction in plasma $\mathrm{Zn}$ concentration at the time of maximum response around 8-12 h after endotoxin but slightly over-compensated before and after this period. Nevertheless it did maintain plasma $\mathrm{Zn}$ concentration at significantly nearer normal values than in the unsupplemented group.

The response of the pigs to endotoxin was assessed on the basis of the four non-subjective measurements presented in Table 4. On average, pigs receiving $\mathrm{Zn}$ ate slightly less food on each of the first two day's following endotoxin administration, had slightly lower plasma aspartate aminotransferase activities and higher bilirubin concentrations but showed the same rise in body temperature. None of the above effects approached statistical significance and possibly of greater importance was the fact that three out of seven pigs infused with $\mathrm{Zn}$ after endotoxin died during the infusion. There were no deaths among the endotoxintreated pigs while receiving a control infusion of physiological saline.

Subjective assessment of the general appearance and behaviour of the pigs used for the measurement of $\mathrm{Zn}$ flux. suggested that the $\mathrm{Zn}$-deficient animals were less stressed by endotoxin than were the control pigs.

\section{DISCUSSION}

Earlier reports had suggested that $\mathrm{Zn}$ in plasma was normally present mainly in an exchangeable form on albumin with a smaller portion relatively firmly bound to $\alpha_{2^{-}}$ macroglobulin (Parisi \& Vallee, 1970; Giroux, 1975; Burns \& Fell, 1976; Song \& Adham. 1979). However in the present experiments with porcine plasma, $\mathrm{Zn}$ was bound to three major components and appeared to be in rapid and complete equilibrium between them. There is obviously a difference in the $\mathrm{Zn}$ distribution in plasma between the pigs and other species (Chesters \& Will, 1981) but recent reports have suggested that even in human plasma the $\mathrm{Zn}$ on $\alpha_{2}$-macroglobulin is not as firmly bound as originally suggested (Parisi \& Vallee. 1970; Adham et al. 1977; Song \& Adham, 1979).

The inability to prevent exchange of ${ }^{65} \mathrm{Zn}$ from albumin to other proteins in porcine plasma limited the interpretation of the results since it was impossible to measure the flux of ${ }^{65} \mathrm{Zn}$ through albumin-bound $\mathrm{Zn}$ per se. However, since the double exponential equations calculated generally accounted for better than $98 \%$ of the variance of the measurements (Fig. 2), it was possible to obtain accurate estimates of the rate of loss of ${ }^{65} \mathrm{Zn}$ from plasma and of the sizes of pools $a$ and $b$ in terms of equivalent volumes of plasma. The derivation of the $\mathrm{Zn}$ content of the pools and the flux of $\mathrm{Zn}$ from these values depended on an assumption as to the fraction of the total $\mathrm{Zn}$ in plasma which was in equilibrium with the injected albumin-bound ${ }^{65} \mathrm{Zn}$. In calculating the results presented it was assumed that only albumin-bound $\mathrm{Zn}$, which accounted for one-third of the total $\mathrm{Zn}$ in plasma, was in equilibrium with the ${ }^{85} \mathrm{Z}_{\mathrm{n}}$ at the time of injection and the values therefore represent minimum estimates of the flux. Maximum estimates could be obtained by assuming 


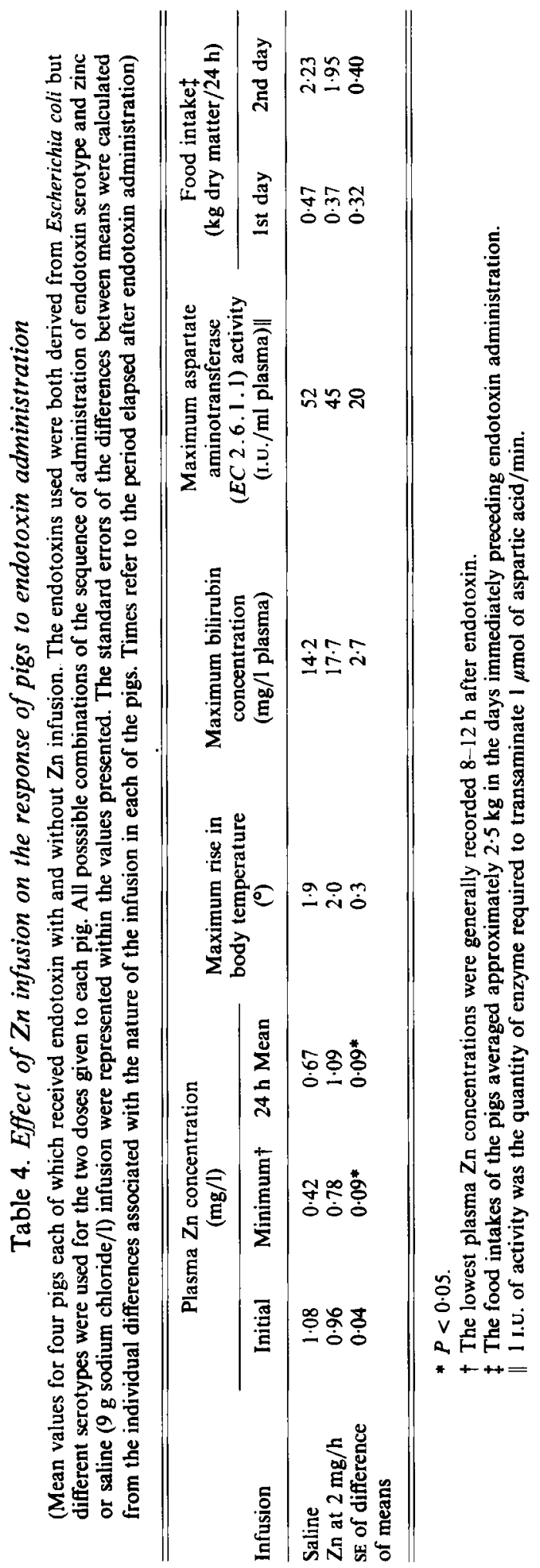


instantaneous equilibration of ${ }^{65} \mathrm{Zn}$ with the total $\mathrm{Zn}$ in plasma and therefore multiplying by three the pool sizes and fluxes presented. When in a preliminary experiment $\mathrm{Zn}$ was infused at three times the rate subsequently used, the plasma $\mathrm{Zn}$ concentration of a stressed pig rose to approximately $2 \mathrm{mg} / \mathrm{l}$ or twice the normal concentration. In $\mathrm{Zn}$-supplemented pigs the calculated difference in $\mathrm{Zn}$ flux through the plasma to the slowly exchanging tissue stores was $1.8 \mathrm{mg} / \mathrm{h}$ when values prior to stressing were compared with those $10 \mathrm{~h}$ after the pigs received endotoxin. When $\mathrm{Zn}$ was infused at $2 \mathrm{mg} / \mathrm{h}$ for $24 \mathrm{~h}$ after endotoxin administration, the plasma $\mathrm{Zn}$ concentration of the pigs remained on average at approximately normal values but was still somewhat low at $10 \mathrm{~h}$. The pool sizes and $\mathrm{Zn}$ flux in pigs should therefore proijably be somewhat higher than those calculated on the present assumptions but much closer to these than to values which would be obtained by assuming instantaneous equilibration of ${ }^{55} \mathrm{Zn}$ with the total $\mathrm{Zn}$ in plasma.

Although the model chosen to explain the ${ }^{65} \mathrm{Zn}$ disappearance curve gave a very close fit between theoretical and experimental values, the biological identity of pools $a$ and $b$ is not clear. Pool a largely represented the $\mathrm{Zn}$ in plasma but, particularly in $\mathrm{Zn}$ deficient pigs, included another significant component. The latter was not accounted for by ${ }^{65} \mathrm{Zn}$ activity in the cells of the blood which was negligible over the first $0.5 \mathrm{~h}$ after injection and the additional component of pool a must therefore have been extravascular in origin. When the urine of the pigs was collected and the ${ }^{65} \mathrm{Zn}$ activity determined, (results not presented) less than $1 \%$ of the ${ }^{65} \mathrm{Zn}$ injected appeared in urine within $24 \mathrm{~h}$. Loss of ${ }^{65} \mathrm{Zn}$ from the plasma was therefore limited initially to uptake by the tissues. Pool $b$ was presumably a summation of those components of tissue $\mathrm{Zn}$ in relatively rapid equilibrium with pool a. The relative constancy of the fractional turnover rates of both pools despite major alterations in their size suggests that the transport mechanism for $\mathrm{Zn}$ was well below saturation at all times. This would certainly have been true for albumin where the value of the molar ratio $\mathrm{Zn}$ : protein would never have exceeded 0.06 .

There were considerable difficulties in assessing both the response of the pigs to endotoxin and the effect of $\mathrm{Zn}$ infusion on the severity of the response. Fever and loss of appetite were probably indicative of the over-all effect of the endotoxin on the animal whereas increased plasma aspartate aminotransferase activity and bilirubin concentration reflected liver damage caused by endotoxin (Utili et al. 1977). Within the restrictions imposed by the limited number of pigs studied there was no indication of a beneficial effect of $\mathrm{Zn}$ infusion, if anything rather the reverse was true. The deaths during $\mathrm{Zn}$ infusion of three of the seven pigs studied strongly reinforced the suggestion that $\mathrm{Zn}$ infusion was not beneficial.

Various other workers have investigated the implications of low plasma $\mathrm{Zn}$ concentrations during stress. Snyder \& Walker (1976) reported a decreased mortality in mice treated with endotoxin when they were dosed intraperitoneally with $\mathrm{Zn}$ either before or at the time of endotoxin administration. Sobocinski, Powander et al. (1977) reported similar findings but showed that the effect was associated with inhibition of uptake of the endotoxin from the peritoneal cavity. The beneficial effect of $\mathrm{Zn}$ appeared to have resulted from a chemical immobilization of the toxin rather than from preventing systemic effects on $\mathrm{Zn}$ metabolism in the animals. In trials with live bacteria, Sobocinski, Canterbury et al. (1977) obtained inconsistent results from $\mathrm{Zn}$ supplementation. With two infections it tended to increase the survival but with a third infection it increased mortality. However, in these experiments, large amounts of $\mathrm{Zn}$ were administered in discrete doses and, in contrast to the present experiments, this resulted in plasma $\mathrm{Zn}$ concentrations far in excess of normal. Whitenack et al. (1978) showed that $\mathrm{Zn}$-deficient pigs were more susceptible to enteric infection than control pigs but these effects probably related to chronic dietary $\mathrm{Zn}$ deficiency rather than to a transient effect of infestion on $\mathrm{Zn}$ flux. Thompson et al. (1976) reported improved nitrogen balances in rats after fracture of the femur if the rats were given increased dietary 
concentrations of $\mathrm{Cu}, \mathrm{Mn}$ or $\mathrm{Zn}$, but here also the major effect of $\mathrm{Zn}$ resulted from small supplements which corrected a dietary deficiency rather than a beneficial effect of $\mathrm{Zn}$ in excess of normal requirements.

Although stress to a normal animal results in a reduction of plasma $\mathrm{Zn}$ concentration and flux comparable with that associated with dietary $\mathrm{Zn}$ deficiency, the balance of the evidence appears to suggest that supplementation with $\mathrm{Zn}$ in excess of normal dietary requirements will not prove beneficial. This is probably not surprising since, whatever the cause of these changes in $\mathrm{Zn}$ metabolism, it seems unlikely that they would have survived evolutionary pressures if they were harmful to the survival of the animal.

The authors wish to thank $\mathrm{Mr} \mathrm{W}$. Watt for purifying porcine albumin and $\mathrm{Mr} \mathrm{A}$. W. Boyne and Mr I. McDonald for advice on the mathematical treatment of the results.

\section{REFERENCES}

Adham, N. F., Song M. K. \& Rinderknecht, H. (1977). Biochim. biophys. Acta 495, 212.

Bullen, J. J., Rogers, H. J. \& Griffiths, E. (1978). Curr. Topics Microbiol. Immunol. 80, 1.

Burns, R. R. \& Fell, G. S. (1976). Scott. med. J. $21,153$.

Chesters, J. K. \& Will, M. (1978). Br. J. Nutr. 39, 297.

Chesters, J. K. \& Will, M. (1981). Br. J. Nutr. 46, 111.

Corrigall, W., Dalgarno, A. C., Ewen, L. A. \& Williams, R. B. (1976). Vet. Rec. 99, 396.

Giroux, E. L.(1975). Biochem. Med. 12, 258.

Hallbook, T. \& Hedelin, H. (1977). Br. J. Surg. 64, 271.

Hallbook, T. \& Hedelin. H. (1978). Acta Chir. scand. 144, 63.

Hambidge, K. M. \& Droegemueller, W. (1974). Obstet. Gynec. N.Y. 44, 666.

Kumar, S. (1976). Nutr. Rep. int. 13, 33.

Parisi, A. F. \& Vallee, B. L. (1970). Biochemistry, N.Y. 9, 2421.

Pekarek, R. S. \& Beisel, W. R. (1969). Appl. Microbiol. 18, 482.

Pekarek, R. S., Burghen, G. A., Bartelloni, P. J., Calia, F. M., Bostian, K. A. \& Beisel, W. R. (1970). J. Lab. clin. Med. 76, 293.

Scott, D. \& McIntosh, G. H. (1975). Q. Jl exp. Physiol. 60, 131.

Shipley, R. A. \& Clark, R. E. (1972). Tracer Methods for in vivo Kinetics, New York and London: Academic Press.

Snyder, S. L. \& Walker, R. I. (1976). Infect. Immunol. 13, 998.

Sobocinski, P. Z., Canterbury, W. J. \& Powanda, M. C. (1977). Proc. Soc. exp. Biol. Med. $156,334$.

Sobocinski, P. Z., Powanda, M. C., Canterbury, W. J., Machotka, S. V., Walker, R. L. \& Snyder, S. L. (1977). Infect. Immunol. 15, 950.

Song, M. K. \& Adham, N. F. (1979). Clinica chim. Acta 99, 13.

Thompson, H. J., Griminger, P. \& Evans, J. L. (1976). J. Nutr. 106, 1421.

Utili, R., Abernathy, C. O. \& Zimmerman, H. J. (1977). Life Sci. 20, 553.

Vikbladh, I. (1951). Scand. J. clin. Invest. Suppl. 2.

Weinberg, E. D. (1974). In Trace Element Metabolism in Animals-2, p. 241 [W. G. Hoekstra, J. W. Suttie, H. E. Ganther and W. Mertz, editors]. Baltimore, Maryland: University Park Press.

Weinberg, E. D. (1978). Microbiol. Rev. 42, 45.

Whitenack, D. L., Whitehair, C. K. \& Miller, E. R. (1978). Am. J. vet. Res. 39, 1447. 